\title{
Sexual problems in disabled people - some key issues
}

\author{
Grażyna Jarząbek-Bielecka', Magdalena Pisarska-Krawczyk²,3 \\ 'Clinic of Gynecology of Department of Perinatology and Gynecology, Division of Developmental Gynecology \\ and Sexuology of Department of Perinatology and Gynecology, University of Medical Sciences, Poznan, Poland \\ ${ }^{2}$ Higher Vocational State School in Kalisz, Poland \\ ${ }^{3}$ Department of Maternal and Child Health, University of Medical Sciences, Poznan, Poland
}

\begin{abstract}
Many disabled persons have to face a hostile environment towards them whenever expressing their sexuality. They find it difficult to receive the healthcare they need for their underlying illness, when combined with sexual problems, due to a lack of experienced doctors and other healthcare staff in such matters. Upon consulting with their gynaecologists about fulfilling their sexual life, disabled women do not always receive satisfactory help, including those who have been victims of sexual abuse, often in childhood, and who in consequence are particularly vulnerable.
\end{abstract}

KEY WORDS: sexual problems, disabled people, sexual health.

ADDRESS FOR CORRESPONDENCE: Magdalena Pisarska-Krawczyk, Higher Vocational State School in Kalisz, 4 Nowy Świat Street, 62-800 Kalisz, Poland, e-mail: magmp@op.pl

Medical interviews with disabled patients in gynaecological and sexological practice show that they do not want to be isolated from healthy people and want to take an active part in social life, to become educated, go to work, to have a sense of stability and acceptance, to have friends and give to others what is best from themselves, including the sexual aspect as being an important part of their lives. The study aim was to demonstrate the sexual problems of people suffering disabilities.

Disabled people are entitled to medical and psychological healthcare and to receive function-based treatment, including being provided with prosthetic and orthopaedic equipment. They also have the right to medical and social rehabilitation, education, vocational training and rehabilitation, disability aids, counselling and employment together with other services enabling them to fully develop their talents and skills and to speed up their social inclusion/reintegration.

Sexuality is one of the fundamental areas/aspects upon which human life is based [1-4]. It fulfils functional needs of procreation, hedonism and relationship bonding. It is an indicator of a favourable, both physical and mental, condition and of the body's general activity [3].
The 'Health for All in 2000' programme, published by the World Health Organization (WHO) in 1986, states that 'Sexual health is the integration of biological, emotional, intellectual and social aspects of sexual life into the beneficial development of personality, communication and love. Sexuality forms an integral part of women's, men's and children's personality. This document further states that the problems of intimacy between disabled people are an extremely neglected area. In order for this situation to change, collaboration is required between specialists in the various fields of science, both medical and non-medical [5].

People with physical disabilities represent about $15 \%$ of the population in Poland [4], and according to the Government Plenipotentiary for Persons with Disabilities (1996) this number is about 3 million. Foreign publications on the sex life of disabled people show that physical impairment places limits on the satisfaction of their emotional and sexual needs $[1,2]$. Such problems may arise from both anatomical limitations (e.g. difficulty in finding a suitable position for both partners to achieve rapprochement), pathophysiological disorders (e.g. loss of the ability to ejaculate after a nerve injury), psycho- 
logical determinants (e.g. low self-esteem, traumatic experiences of unrequited love) and anthropological factors (e.g. fixed models on the socio-biological roles of women and men). In addition, there are still abnormal stereotypes abounding with regard to the intimate life of people with disabilities.

Parents or guardians commonly perceive disabled children as being sexually abstinent, which complicates the investigation of this problem along with their rehabilitation. Parents of disabled children should also be made aware of the problem that children with intellectual and physical disabilities are particularly vulnerable to, and are often victims of, sexual offenses [5-9]. Numerous sociological observations indicate that Polish society is very traditional, showing in this respect many negative stereotypes that have long since been absent in EU countries. One of them is the supposed asexuality of the disabled person. The false conception of this stereotype has led to gynaecological and sexual health rehabilitation being marginalised, which is often encountered in the carers of the disabled, guidance counsellors and also in physicians.

Clinical observations in gynaecological and sexological practice show that when interviewed, disabled patients underline that they do not want to be isolated from healthy people and want to take an active part in social life, to be educated, be employed, to have a sense of stability and acceptance as well as to make friends and offer the best of themselves to others. Disabled patients talk about seemingly irreconcilable issues: joy and calm in suffering, trust despite painful experiences, and striving to be a fit disabled person. Despair, resignation or inner struggle is transformed into constructive action. Some disabled people even say that since becoming disabled, they have started a new and richer life. There are few studies published in the national and international literature providing a detailed analysis of the emotional and sexual needs of people with mobility disabilities; in such patients, those people who were sexually active before the time of their disability are predominant. Thus, these people already possess some knowledge and experience of their own sexuality, and the main therapeutic goal is only in psychological-medical support in the forging of sexual function anew. An important determinant of the effectiveness of therapy is the moment when it starts. The earlier it is included in the rehabilitation process, the less is the risk of secondary psychological castration of a person after a spinal cord injury.

In a Radomski-group study, subjects consisted of people who had become disabled before sexual initiation. This research was based on a specially prepared questionnaire consisting of 38 questions including ones on: the environment in adolescence, self-evaluation of selected personality traits, physical impairment and evaluating their sex lives. There were 69 people diagnosed with disabilities prior to their sexual initiation; $52 \%$ were women and $48 \%$ were men, with their average age being 25.11 \pm 8.38 years. The youngest subject was 15 whilst the oldest was 49 years [9]. Every second subject expressed the desire for using sex counselling. There was no correlation between the extent of motor disability and sexual activity. The Radomski study identified those factors impeding both sexual initiation and in forming partner relationships. The commonly found isolation of such persons from peers can adversely affect the process of mentalising and concretising sexual desire.

The Radomski study also found that the over-controlling influence of the parents of disabled persons limits their ability to gain reliable knowledge and sexual experience. These facts contribute to a statistically significant delay in the age of sexual initiation of disabled people compared to those without disabilities. The need for widespread sexual education in this group was also highlighted, where emergence of an increasing number of school-based integration centres was favoured, which constitute a natural environment for the socialization of disabled children. One way to reduce those factors that impede the sex life of disabled people may be to include these issues in mass/large-scale sexual education programmes. By such means, both the stereotypes of alleged 'asexuality' and feelings of complete helplessness of a disabled person during intimate contact can be changed. Sadly, from childhood, people with disabilities are more likely to be victims of sexual abuse and thus they should take care of their safety through the following:

- ignore 'suspicious' proposals,

- never go away with strangers,

- defend yourself in all ways possible when in danger,

- inform close friends about situations that seem strange or threatening,

- don't open the door to strangers,

- keep away from isolated places.

In view of the existing threats, one should learn to take care of oneself. Because of the so-called date-rape pills used by criminals, the following principles apply:

- never leave an opened beverage at parties,

- keep to a moderate alcohol intake (many date rapes occur when victims are drunk),

- if you feel unwell, seek help from a trusted person or security staff and avoid dark places (having taken a date-rape pill the victim is often ready to leave the party with the first person they meet).

What actually is a date-rape pill/drug or a rape cocktail? These terms refer to psychoactive substances, most commonly depressants such as gamma-hydroxybutyrate (GHB) and flunitrazepam, which cause drowsiness and amnesia lasting a few hours. These substances act insidiously and when dissolved are tasteless, odourless, do not change the colour of the drink and are readily soluble in water, juice, beer and other drinks. They start to act several minutes after ingestion [4-7]. It is important for caregivers of the disabled to be aware of the above and 
to additionally ensure that, in addition to providing adequate sex education, the disabled are well informed that disabled people, who are particularly vulnerable to sexual violence, should always care about their safety.

\section{CONCLUSIONS}

Literature review and clinical observations show that, despite difficulties in meeting their sexual needs, disabled people declare a lively interest in their sexuality, which is an important part of their lives. However, the small numbers of specialist staff in sexology, coupled often with economic constraints, prevent disabled people from getting professional help. It is hoped that systematic and creative solutions will be developed to deliver answers to sexual issues concerning disabled people [7-9].

\section{DISCLOSURE}

Authors report no conflict of interest.

\section{References}

1. Berkman AH, Weissman R, Frielich MH. Sexual adjustment of spinal cord injured veterans living in the community. Arch Phys Med Rehabil 1978; 59: 29-33.

2. Halstead LS, Halstead MG, Salhoot JT, et al. Sexual attitudes, behavior and satisfaction for able bodied and disabled participants attending workshops in human sexuality. Arch Phys Med Rehabil 1978; 59: 497-501.

3. Imieliński K. Zarys seksuologii i seksiatrii [Outline of sexology and sexiatrics]. PZWL, Warszawa 1982.

4. Jarząbek-Bielecka G, Radomski D, Bielecki M. O opiece ginekologicznej i seksuologicznej nad pacjentką niepełnosprawną (z uwzględnieniem poradnictwa aptekarskiego) [About gynecological care and sexually abusive patient (Including pharmacy counselling)]. In: Nauka o płci. Zagadnienia wybrane. Jarząbek-Bielecka G (ed.). Poznań, 2012; 183-207.

5. Jarząbek-Bielecka G, Sowińska-Przepiera E, Milewczyk P. Problem opieki nad dziewczętami i kobietami niepełnosprawnymi [The problem of taking care of girls and women with disabilities]. Ginek Prakt 2010; 18: 36-42.

6. Lew-Starowicz Z. Życie intymne osób niepełnosprawnych [Intimate life of people with disabilities]. Wydawnictwo Severus, Warszawa 1999.

7. Jarząbek G, Radomski D. Specyfika opieki ginekologicznej i seksuologicznej nad kobietami niepełnosprawnymi w okresie pomenopauzalnym z uwzględnieniem aspektów etycznych [Specificity of gynecological and sexological care for postmenopausal women with disabilities including ethical aspects]. Prz Menopauz 2011; 10: 63-67.

8. Radomski D. Telemedical systems as integral part of internet service for disabled persons. Internet for disabled people. Today \& Tomorrow, Warsaw 2000.

9. Radomski D. Czynniki utrudniające realizację życia erotycznego osób niepełnosprawnych fizycznie [Factors impeding the realization of the erotic life of physically disabled people]. Seksuologia Polska 2005; 3: 8-12.

\section{AUTHORS' CONTRIBUTIONS}

GJB, MPK prepared the research concept, collected data, wrote the article and finally approved it. 